Relations industrielles

Industrial Relations

\title{
Stone, Thomas H., and Noah M. Meltz, Human Resource \\ Management in Canada
}

\section{Denis Morin}

Volume 49, numéro 1, 1994

URI : https://id.erudit.org/iderudit/050926ar

DOI : https://doi.org/10.7202/050926ar

Aller au sommaire du numéro

Éditeur(s)

Département des relations industrielles de l'Université Laval

ISSN

0034-379X (imprimé)

1703-8138 (numérique)

Découvrir la revue

Citer ce compte rendu

Morin, D. (1994). Compte rendu de [Stone, Thomas H., and Noah M. Meltz, Human Resource Management in Canada]. Relations industrielles / Industrial Relations, 49(1), 190-195. https://doi.org/10.7202/050926ar

Tous droits réservés (C) Département des relations industrielles de l'Université Laval, 1994
Ce document est protégé par la loi sur le droit d'auteur. L'utilisation des services d'Érudit (y compris la reproduction) est assujettie à sa politique d'utilisation que vous pouvez consulter en ligne.

https://apropos.erudit.org/fr/usagers/politique-dutilisation/ 
assujettie à la négociation collective. L'auteur montre comment les structures de négociation et les modalités d'exercice du rapport de force ont évolué depuis 1964. Après avoir fait ressortir le degré de centralisation du régime, il note qu'environ la moitié des négociations entre 1966 et 1989 ont été marquées par un conflit de travail. Pour ce qui est des résultats, la rémunération offerte à ces salariés est équivalente à celle offerte dans le secteur privé syndiqué. À la lumière des événements des dernières années et du contexte économique des années 1990 , l'auteur conclût en se demandant si la consultation n'est pas en train de remplacer la négociation dans le secteur public. Cette incursion dans le secteur public se termine par deux textes présentant pour l'un, une expérience innovatrice de négociation dans le secteur de la santé et pour l'autre, une approche syndicale pragmatique à l'égard des revendications contractuelles dans le secteur de l'éducation.

Charles Heckscher comme dernier auteur principal traite des différentes solutions alternatives à la crise à laquelle le syndicalisme et la négociation sont confrontés aux États-Unis. Après avoir rapidement écarté l'option d'un plus grand militantisme syndical et celle de la réforme des lois du travail, l'auteur présente une troisième voie qui passe par une redéfinition de la nature du syndicalisme. Cette dernière comprend une décentralisation de l'action syndicale impliquant une alliance étroite avec les mouvements sociaux et reposant sur l'activisme de ses membres, réduisant ainsi l'importance de la convention collective. L'auteur enchaîne en dégageant de l'expérience américaine chez AT\&T les éléments qui permettraient de redéfinir la nature et la forme des relations patronales-syndicales. Ce texte est suivi de cinq courtes présentations de praticiens des relations industrielles qui exposent à tour de rôle les perspectives syndicale, patronale et gouvernementale à l'égard de la transformation de la négociation collective.

Malgré les faiblesses découlant d'un certain manque de cohésion entre les textes, cet ouvrage permet une meilleure compréhension du renouvellement des relations de travail au Québec. L'heureux mariage de textes de chercheurs universitaires et de praticiens enrichit l'explication proposée. Même si certains textes se contentent avant tout de présenter la situation actuelle, la plupart sont aussi normatifs, en ce sens que la coopération ou la concertation entre les parties est présentée comme la pierre angulaire d'une sortie de crise pour les relations industrielles. Cette idée est intéressante en soi, mais il aurait aussi été utile d'envisager d'autres perspectives comme la modification de l'action syndicale proposée par Charles Heckscher pour entre autres établir la négociation collective dans les services privés. En somme, il s'agit d'un bon ouvrage qui permet de faire le point et qui propose une réflexion enrichissante sur le futur de la négociation collective.

Université du Québec à Hull

Université de Montréal

Renaud PaQuet Jean-Guy BERGERON

Human Resource Management in Canada, 3d ed., by Thomas H. SToNE and Noah M. Meltz, Toronto, Dryden (Holt, Rinehart and Wiston of Canada), 1993, 807 p., ISBN 0-03-922797-9.

This book designed primarily for undergraduates has earned wide acceptance and a well deserved reputation for quality. Readers familiar with the first and second editions will expect a text of high quality. I doubt they will be disappointed. 
This book is based on the theme of strategic human resource management. The value of using this theme is very well developed in Chapter 1 and applied throughout the book. The starting point for the model is that organizational goals and objectives and strategic planning are achieved through HRM. The model views the major HRM responsibilities and their related functions as strategic analysis (development of HR strategic objectives); planning (job analysis, human resource planning); staffing (recruitment, selection); development (orientation, training and development, career planning, performance appraisal); employee maintenance (compensation, benefits, health and safety, labour relations). All HRM functions are guided by the basic objective of ensuring an adequate number of competent employees with needed skills, abilities, knowledge and experience to support organizational goals and objectives and strategic planning. The HRM outcomes are divided into three broad categories: performance, satisfaction and enhancement of appropriate and desired behaviour (e.g. reducing employee withdrawal behaviour). The model further recognizes that all HRM functions and outcomes are affected by external factors such as economic and market forces and the legal/regulatory environment.

Structurally, the book consists of 16 substantive chapters organized into five parts. Part I serves as an introduction to the rest of the book and consists of three chapters dealing with the HRM strategic function and the social and legal contexts of HRM. The book's emphasis on strategic considerations is intended to reflect the growing influence of human resources specialists in corporate decision making. Stone and Meltz make a convincing case for why human resources practitioners should expect to achieve an equal footing on the strategic level with their counterparts in marketing, production and finance. There is little question that the evolution of the personnel function into a human resource function is a change in more than name only. The book is at its best when it deals with the ways in which HRM activities are influenced by the organization's internal and external environment and the ways in which HRM activities influence organizational outcomes. For example, the authors note the prevalence of change in all aspects of HRM: technology dictating more complicated job requirement; an older workforce; more females in the workforce; and a greater role for HRM in the corporation, tempered with a greater accountability for its action.

One of the best chapters covers the legal context of HRM and preaches an important message about the compatibility of legal requirements and sound HRM. Early in the book, the authors briefly review various Canadian laws that apply to HRM. These laws receive more detailed treatment as they relate to the material in the various chapters. Stone and Meltz focus on six areas of the legal environment in personnel and human resource management: equal employment opportunity, employee safety and health, employee pay and benefits, employee job security and union management relations.

The next three parts, each of which contains four chapters, reflect the more traditional personnel function. Part II, entitled "Planning and Staffing", deals with human resource planning, job analysis, recruitment and selection. Chapter 4 examines how human resource planning (projecting future HR supply, forecasting future HR needs, comparing forecasted needs with projected supply, plan policies and programs, evaluating HR planning effectiveness) is related to organizational goals and objectives and strategic planning. A brief summary of approaches for evaluating the effectiveness of 
HR planning function is presented. Stone and Meltz touch on the major points of the HR audit but do not treat the topic in its full complexity. The authors discuss the human resource information system as an appropriate technology that can certainly aid HR managers in thinking and planning ahead, thereby facilitating their ability to make more effective use of human resources in organization.

Chapter 5 covers the role of job analysis in HRM, including the importance of job analysis, the source of such data, techniques for collecting it and methods of analyzing it. The authors review recent research and trends in job analysis. Each of the major job analysis methodologies (observation methods, interview techniques, combined observation/interview approaches, questionnaires including job inventories or checklists) is touched upon prior to exploring the reliability and validity of job analysis.

The effectiveness of different recruitment sources is examined in Chapter 6 . The authors do a very good job of describing the various elements of the internal and external environments affecting the recruiting process (e.g. organizational characteristics, type of labour, labour market conditions, legal requirements, cost and time constraints). This chapter is solid but very similar to what is found in most quality texts.

The focus of Chapter 7 is on the methods used to select people for employment. The selection procedure should optimize the person-job fit and thereby increase the degree to which organizational productivity goals are achieved. Based on recent work on utility measurement, Stone and Meltz indicate that valid selection procedures can add substantially to organizational productivity. For those unfamiliar with the concept of utility, the authors provide a brief but lucid technical appendice. Each personnel selection method is evaluated against criteria of reliability and validity. The various forms of validity are described in some detail. Stone and Meltz state that one of the ironies of employment practices is that the interview, despite its questionable validity, remains the most frequently used decision tool. A model that demonstrates the various types of influences that may affect employment interviews and their outcomes is presented, but more information is needed to understand the dynamic properties of the interview process. The authors provide many applied tips/guidelines for conducting selection activities. The coverage of assessment centers is fairly standard.

Part III, entitled "Employee Development", is devoted to employee orientation, training and development, career planning and performance appraisal. Employee orientation is examined in Chapter 8, which covers the effect of realistic job previews and the organizational socialization process of newcomers. Stone and Meltz discuss the factors that influence newcomers' learning process or reaction to their new organizational roles.

Chapter 9 explores how training can be utilized to support organizational strategy. Training needs analysis is discussed in the traditional format (organizational, task and person analyses with a performance discrepancy model). The authors describe training techniques and offer suggestions as to how the trainer can use each method more effectively. Furthermore, the authors offer several recommendations for ensuring a transfer of learning. Nevertheless, some mention should have been made of the relapse prevention model and organizational and social factors that need be taken into account in order to increase training effectiveness. The final part of the chapter describes how to conduct 
and evaluate training programs. The authors have provided a discussion of evaluation designs and criteria (e.g. learning, behavior, results).

Another good chapter is that which treats on career planning where the authors raise many timely issues, such as dual career couples. However, relatively little discussion is devoted to the management of older workers. The career planning chapter is well organized and more extensive than in most other HRM texts.

A rather complete collection of performance appraisal methods is presented in Chapter 11. This chapter focuses also on the processes used to design performance appraisal systems. We find a comprehensive discussion on how to conduct a feedback interview. However, the chapter should have included a more extensive discussion on the influence of the rating context on the rating outcome. The organizational context adds greatly to our understanding of likely sources of distortion. Given that organizations expend a considerable amount of scarce resources to develop and implement performance appraisal systems, the issue of rater motivation is of practical importance as well. The authors should have devoted more than a single page to this critical topic.

Part IV, entitled "Employee Maintenance" - by far the strongest part of the book - addresses compensation, benefits, employee health and safety, and labour relations. In Chapter 12, the authors focus on the manner in which compensation programs can be used to implement and support strategic change, and, more importantly, how compensation programs can be used to develop more effective organizations. The four major job evaluation techniques (ranking, classification, factor comparison and point method) are presented. The authors are also concerned with how best to conduct job evaluation, since job evaluation is viewed as inevitable for determining pay equity. The tone of the chapter suggests that union involvement is the most promising method of achieving comparable worth. Job evaluation is not only defined, but the difficulties of using job evaluation to set wages are described. Stone and Meltz also examine individual wage determination, focusing on seniority, merit pay, skill based pay and individual and group incentives.

Chapter 13 examines benefits programs, paying particular attention to the importance of benefits surveys and the components of the benefit package. The value of surveying employees to determine their benefits preference is discussed.

Stone and Meltz restrict the scope of Chapter 14 on employee health and safety almost exclusively to regulation in Ontario and British Columbia, leaving virtually untouched several other provincial health and safety regimes. The authors provide enough background on health problems - such as job stress and burnout, smoking, alcoholism, the use of drugs, and AIDS - so that the reader can fully appreciate the ways in which these health problems affect organizational effectiveness. Topics of current interest, such as employee assistance program, also receive some treatment.

Chapter 15, dealing with union/management relations, is one of the unique attractions of the text. However, when discussing the collective agreement, the authors do not emphasize in sufficient details the ways in which bargaining issues have been affected by recent environmental change and their consequences on the organization (for example: the recession and concession bargaining). 
In the last part of the volume consisting of one chapter, the authors provide a nice ending to the book through the presentation of a worthwhile discussion of current and projected trends of HRM next few years. However, the book might have also included a final section to deal explicitly with international HRM.

The book appears to some extent conservative. While it treats the traditional topics of HRM very effectively, a " political influence" perspective could have been used to examine systematically several key areas of HRM (e.g. selection, performance appraisal, compensation). Stone and Meltz should work in this direction in future editions.

Stone and Meltz's book is largely based on one major assumption: people matter. However, given the popular total quality management (TQM) movement, it is surprising that the authors have not examined TQM or system approaches to HRM. A model of HRM that considers both person and system factors is badly needed.

HRM activities are commonly evaluated in behavioral terms. However, the need to evaluate HRM activities in economic terms is becoming apparent. HRM can stand right alongside the other functional areas of business when HRM outcomes are measured in dollars. Unfortunately, few HR managers take the time to analyze the financial benefits of HRM programs. HR managers would benefit by taking advantage of methods now available for demonstrating the contribution of the HRM function to their organizations. Stone and Meltz should include a new chapter on methods for estimating costs and benefits of HRM.

The book has a number of positive features to recommend it. To start with, it is well written. The authors are able to present sophisticated concepts in a manner that should be clear to most readers. In addition, the volume has a strong research base and yet balances theory with practical applications. Stone and Meltz do a fine job with this approach. Many of the references are very recent, some as late as 1992, and they are taken from the best research and professional litterature. The most frequently cited journals include Personnel Psychology, the Journal of Applied Psychology, HR Magazine, and the Personnel Administrator.

Several pedagogical devices are incorporated in the text, including a series of insets entitled "HRM in Action" which summarize recent developments in each of the HRM functions. These are usually one page excerpts from relevant periodicals and books in the field. A second feature consists of two extensive end-of-chapter cases and several project ideas. This may be the strongest application feature of the book. A video case is also available as an ancillary for each of the five parts of the book. The cases are well done and the review questions at the end of each chapter are varied and thoughtful. The suggestions for further reading following each chapter are very useful for further investigation of specific issues.

The book provides consistently good coverage of the standard subjects of HRM. The lay out and construction of the book is outstanding. The authors achieved their purpose of bringing research in HRM to the undergraduate level in a way that students will enjoy but that will maintain academic standards. The book provides the depth and breadth needed in a undergraduate HRM course. The book would be especially valuable 
in an HRM survey course that is aimed at students from other disciplines. The basic goal of matching closely the textbook to the course is achieved.

Denis Morin

Université Laval

Japanization at Work, by John BRATTON, London, Macmillan, 1992, 244 p., ISBN 0-333-54574-5

There has been a continual stream of schemes - Quality of Working Life (QWL), Team Concept, Quality Circles, Total Quality Management (TQM), Lean Production, Just in Time (JIT), Synchronous Manufacture, etc. - largely inspired by envy of Japanese production techniques, which have been designed to increase job satisfaction for workers and cut company costs. One emphasis is derived from the realization that, in traditional companies, once at work many employees have little control over how they spend their time and that employers are not very interested in what workers think. The other stems from the need to meet the competitive challenge, to match Japanese management techniques, and generally to cut out "waste".

This renewed focus on human resources is helping to redefine human resource management as central to organizational success. The initial concerns of manufacturing companies have spread to service companies and public sector organizations. Consultants abound spreading this new gospel; managers are redefined as "leaders" and "coaches", workers as "associates" or "members", and factories and offices as "learning organisations".

Some of the writing in this area stems from a belief that we are now living in a "post-industrial society", and that "Fordist" mass production techniques based on Frederick Taylor's "scientific management" approach to work organization is no longer appropriate. For some authors adversarial union attitudes are also seen as inappropriate in this perceived new climate. "Toyotarist" production methods are sometimes contrasted and are depicted as collaborative and using "cell" production techniques rather than the assembly line; claims are made that production is more differentiated than it was previously with companies competing more on quality than price.

Although there has been a shift away from mass production techniques and industry, and an extension of service employment together with a move towards smaller production units, many of the jobs in both services and industry remain repetitive, largely unchallenging, and are low paid (for example employment in fast-food outlets - often referred to as "Mac-jobs" - are low skill and low paid part-time jobs). Therefore this shift to post-industrial society and towards new participatory management styles is overstated.

There have been a number of reports of companies' successful conversion to this new management style (for example the regular features in the Globe and Mail); reports, often supplied by consultants, emphasize how workers have greater control over the design of their job, how they are contributing much more to the organization, where 